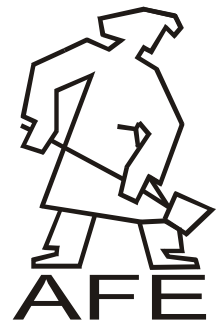

\title{
The Effect of Nodular Cast Iron Metal Matrix on the Wear Resistance
}

\author{
G. Gumienny* \\ Department of Materials Engineering and Production Systems, Technical University of Łódź \\ Stefanowskiego 1/15 Street, 90-924 Łódź, Poland \\ *Corresponding author: E-mail address: grzegorz.gumienny@p.lodz.pl
}

Received 25-05-2012; accepted in revised form 31-05-2012

\begin{abstract}
The paper presents results of studies on the effect of the nodular cast iron metal matrix composition on the abrasive and adhesive wear resistance. Nodular cast iron with different metal matrix obtained in the rough state and ADI were tested. To research of abrasive and adhesive wear the pearlitic and bainitic cast iron with carbides and without this component were chosen. The influence of the carbides amount for cast iron wear resistance was examined. It was found, that the highest abrasive and adhesive wear resistance under conditions of dry friction has a nodular cast iron with carbides with upper and lower bainite. Carbides in bainitic and pearlitic cast iron significantly increase the wear resistance in these conditions. In terms of fluid friction the largest wear resistance had cast iron group with the highest hardness.
\end{abstract}

Keywords: Innovative Foundry Technologies and Materials, Nodular Cast Iron with Carbides, Wear Resistance

\section{Introduction}

During last few years in the Department of Materials Engineering and Production Systems of Technical University of Łódź the technology of manufacturing in the rough state of bainiticmartensitic nodular cast iron with carbides was developed [1-6]. Conducted research demonstrated its high wear resistance $[7,8]$. Comparative studies of ADI (defined as highly wear resistant) were executed too.

The aim of this study was to investigate the abrasive wear resistance of different types of nodular cast iron and adhesive under conditions of dry and fluid friction mating with C55 steel with martensitic microstructure.

\section{Work methodology}

To study a nodular cast iron with the chemical composition presented in Table 1 was used.

The chemical composition of each cast iron was tested with using SPECTROMAXx stationary metal analyzer made by Spectro Analytical Instruments $\mathrm{GmbH}$.

ADI ausferritic microstructure was obtained after austenitizing for $1 \mathrm{~h}$ at $900^{\circ} \mathrm{C}$ and tempering at $375^{\circ} \mathrm{C}$ for $1 \mathrm{~h}$. Microstructure of pearlitic, bainitic and carbides were obtained in nodular cast iron in the raw state after nodularizing in mould.

The proportion of metal matrix components were examined using NIS-Elements BR image analysis program.

The hardness of cast iron was tested with use of HPO hardness tester for the conditions: 2,5/187,5/30.

Tribological tests were performed on the special test station, whose scheme is shown in Figure 1. 
Table 1.

The chemical composition of the examined types of nodular cast iron

\begin{tabular}{|c|c|c|c|c|c|c|c|c|c|}
\hline \multirow{2}{*}{ No. } & \multirow{2}{*}{$\begin{array}{l}\text { Type of cast iron metal matrix } \\
\text { and the proportion of the components }\end{array}$} & \multicolumn{8}{|c|}{ Chemical composition, $\%$} \\
\hline & & $\mathrm{C}$ & $\mathrm{Si}$ & $\mathrm{Mn}$ & $\mathrm{Cr}$ & Mo & $\mathrm{Ni}$ & $\mathrm{Cu}$ & $\mathrm{Mg}$ \\
\hline 1. & ausferrite $100 \%$ & 3,41 & 2,61 & 0,30 & - & - & - & 0,48 & 0,05 \\
\hline 2. & pearlite $100 \%$ & 3,83 & 2,42 & 0,37 & - & - & 0,93 & 1,44 & 0,04 \\
\hline 3. & pearlite $90 \%$, carbides $10 \%$ & 3,88 & 2,23 & 0,40 & 0,99 & - & 0,96 & 1,55 & 0,05 \\
\hline 4. & upper bainite $100 \%$ & 3,80 & 1,93 & 0,05 & - & 1,37 & 1,01 & - & 0,04 \\
\hline 5. & upper bainite $95 \%$, carbides $5 \%$ & 3,30 & 2,27 & 0,08 & - & 2,00 & 1,06 & - & 0,05 \\
\hline 6. & upper bainite $88 \%$, carbides $12 \%$ & 3,72 & 1,94 & 0,06 & 0,36 & 1,82 & 0,96 & - & 0,05 \\
\hline 7. & upper bainite $67 \%$, lower bainite $30 \%$, carbides $3 \%$ & 3,52 & 2,40 & 0,28 & - & 1,51 & 1,67 & - & 0,05 \\
\hline
\end{tabular}

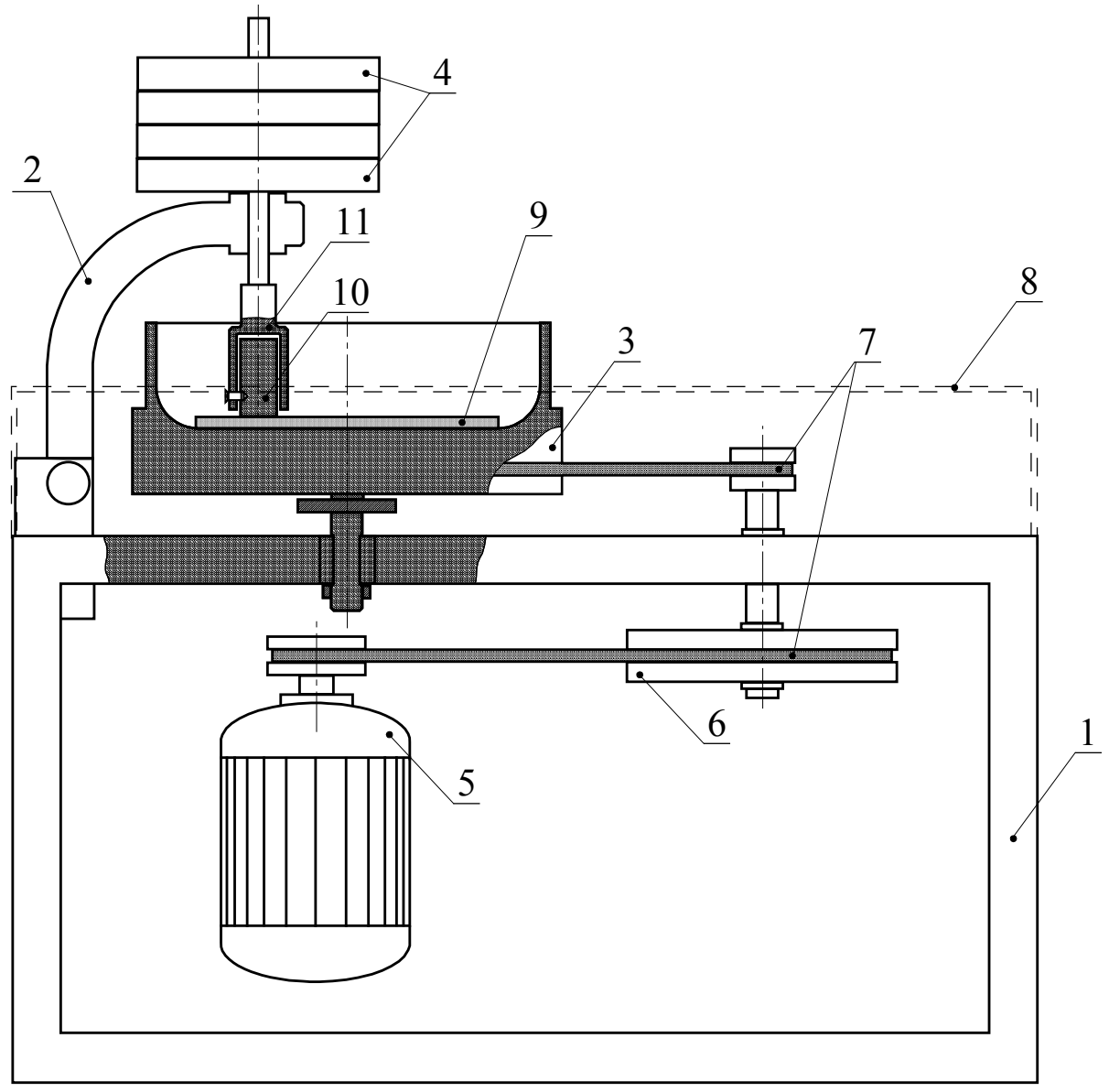

Fig. 1. The scheme of abrasive and adhesive wear testing stand: 1 - housing , 2 - mobile lever, 3 - revolving pan, 4 - load, 5 - engine, 6 - flywheel, 7 - driving belts, 8 - cover, 9 - abrasive paper or counterface, 10 - specimen, 11 - specimen holder 
Dimensions of specimens for abrasive and adhesive wear resistance of cast iron are shown in Figure 2.

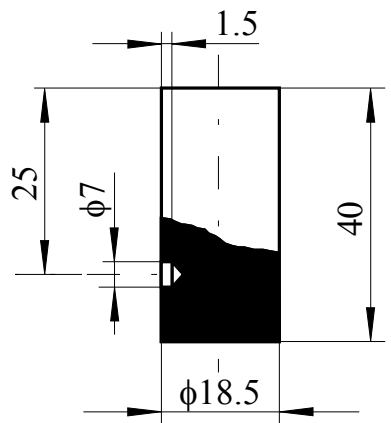

Fig. 2. Dimensions of specimens for abrasive and adhesive wear resistance

The test conditions were as follows:

- load the sample on a counter sandpaper and steel: $\mathrm{F}=98.0655 \mathrm{~N}$,

- $\quad$ abrasive surface of the sample: $\mathrm{S}=268.8 \mathrm{~mm}^{2}$,

- $\quad$ sample unit pressure:

$$
\sigma=\frac{F}{S}=\frac{98.0665 \mathrm{~N}}{268.8 \mathrm{~mm}^{2}}=0.36 \mathrm{MPa}
$$

- rotational speed: $\omega=75$ RPM.

To cast iron abrasive resistance testing the abrasive paper with the grit size 40 was used.

For testing resistance to adhesive wear of cast iron were used as a counterface disc with a diameter $\phi 100 \mathrm{~mm}$ and $10 \mathrm{~mm}$ thick made of C55 non-alloy steel for toughening. It had hardening and low tempering. Its microstructure is shown in Figure 3.

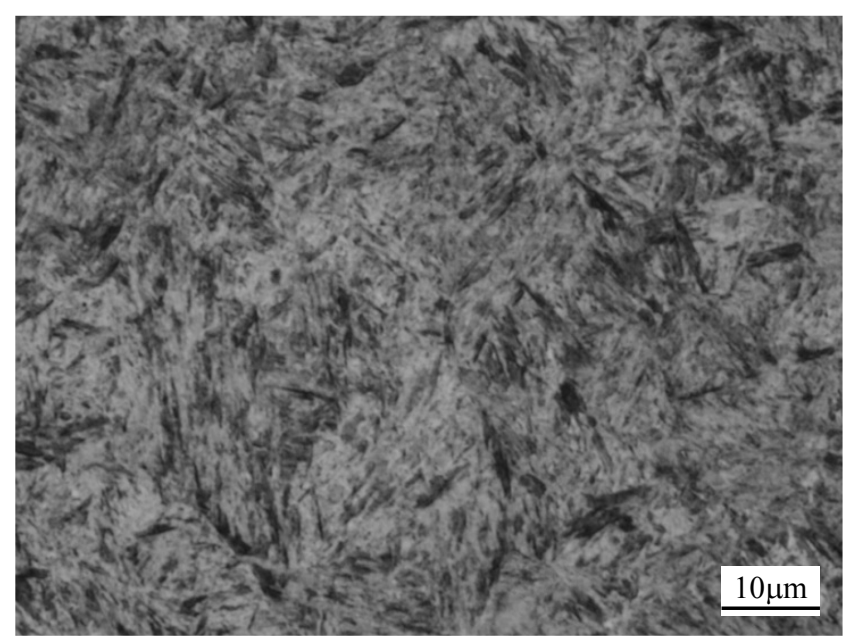

Fig. 3. Counterface microstructure steel after hardening and low tempering: low-tempered martensite, retained austenite, nonmetallic inclusions
Adhesive wear was studied in dry friction conditions and using Castrol Magnatec 10W40 oil.

Microstructure of cast iron and steel counterface were examined on nital etched metallographic specimens at a magnification of $\times 1000$ for Eclipse MA200 Nikon metallurgical microscope.

The sample mass loss was measured on an electronic scale measuring a "Sartorius CP 224S-OCE" with an accuracy of $0.0001 \mathrm{~g}$ (measurement error $\pm 0.0003 \mathrm{~g}$ ).

\section{Results}

In Figure $4(\mathrm{a} \div \mathrm{g})$ the microstructure of the investigated kinds of cast iron is shown.

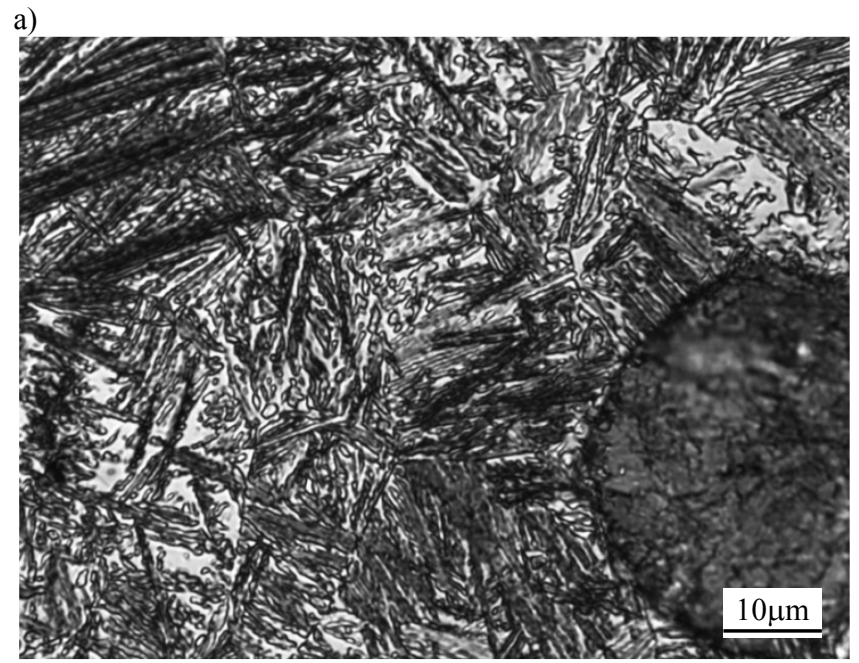

b)

microstructure: nodular graphite, ausferrite

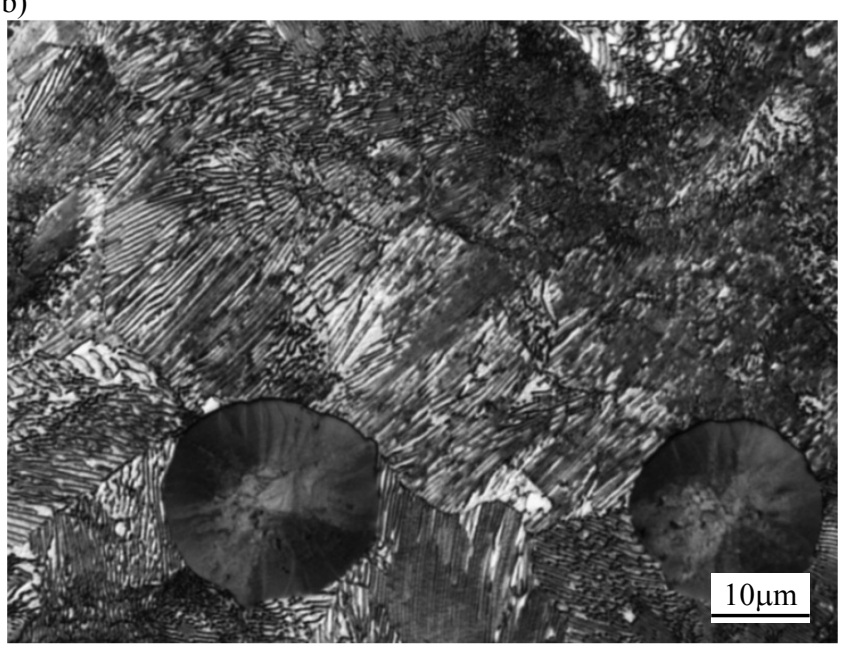

microstructure: nodular graphite, pearlite 
c)

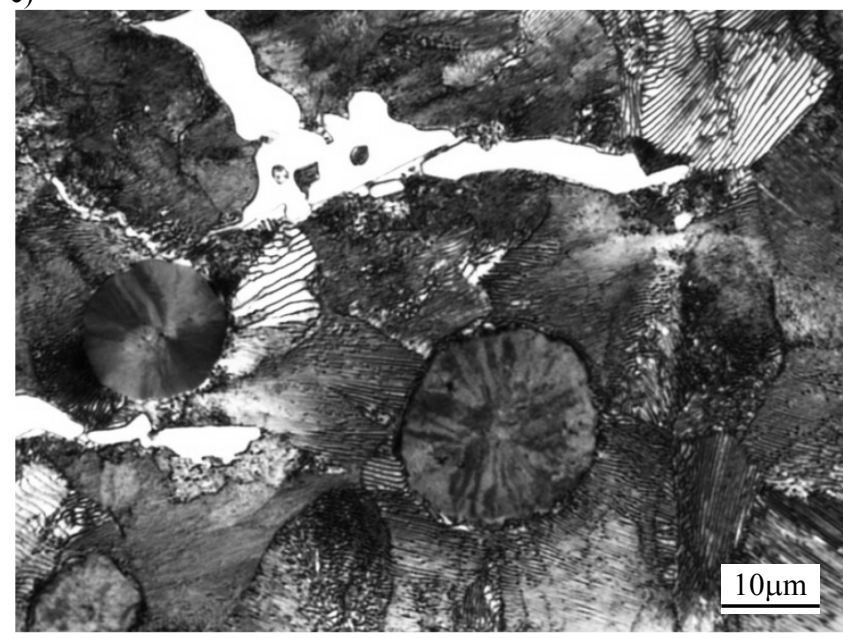

microstructure: nodular graphite, pearlite, carbides

d)

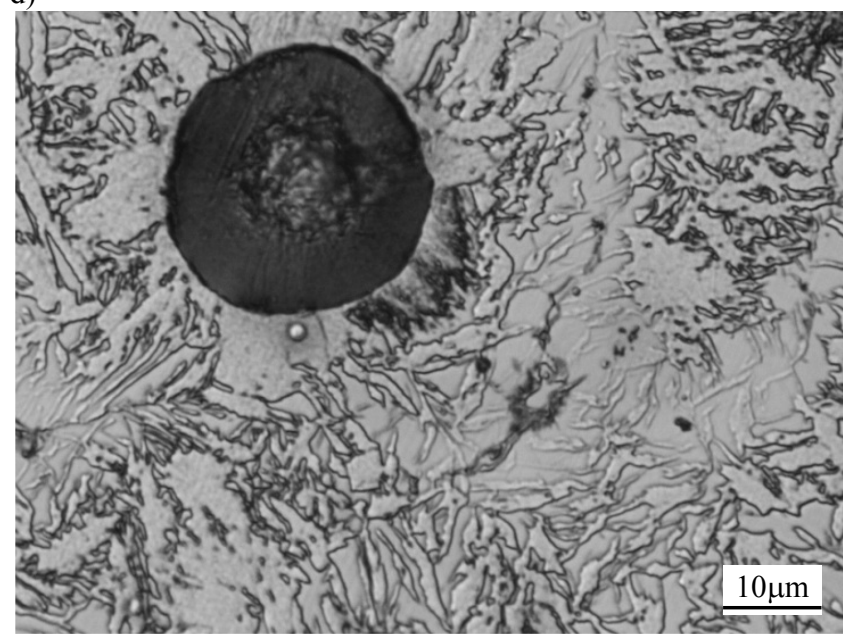

microstructure: nodular graphite, upper bainite

e)

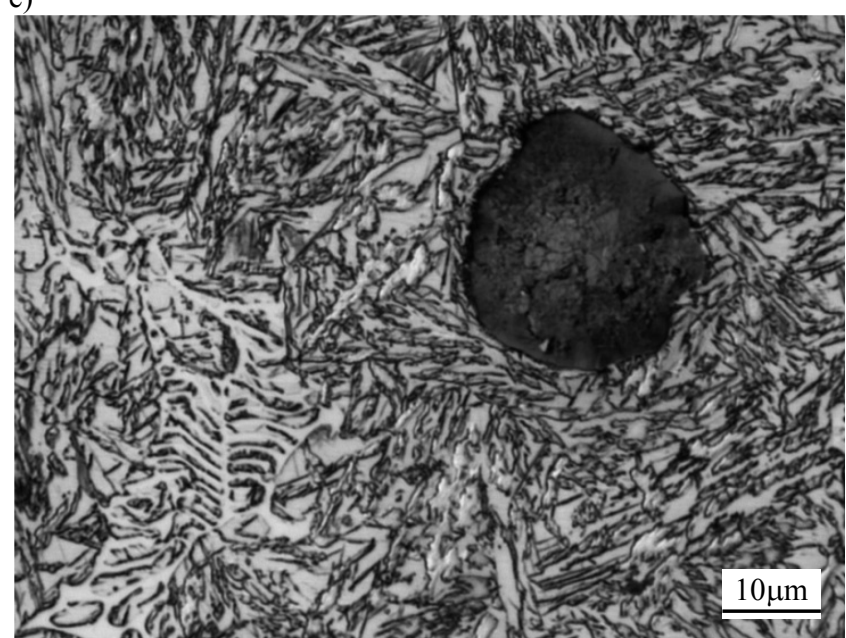

microstructure: nodular graphite, upper bainite, carbides

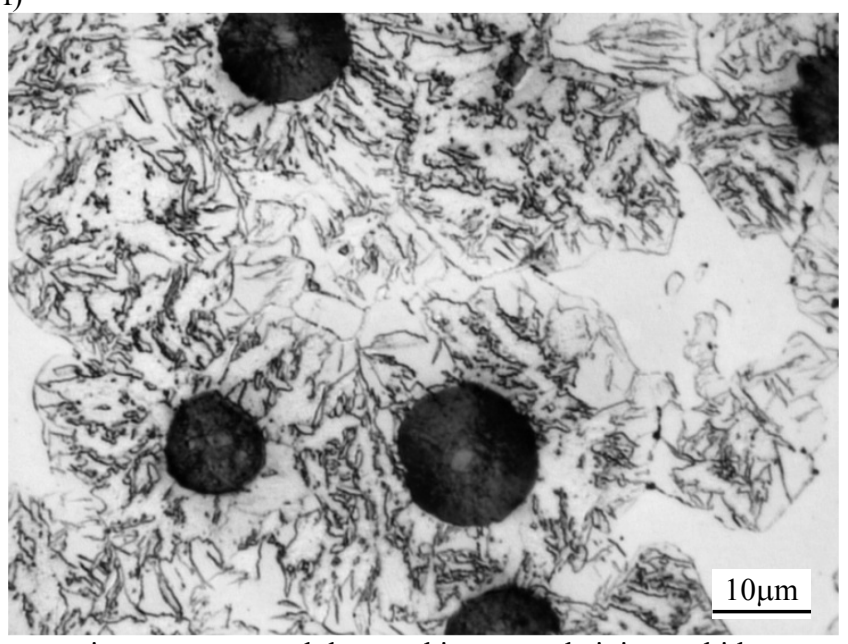

microstructure: nodular graphite, upper bainite, carbides

g)

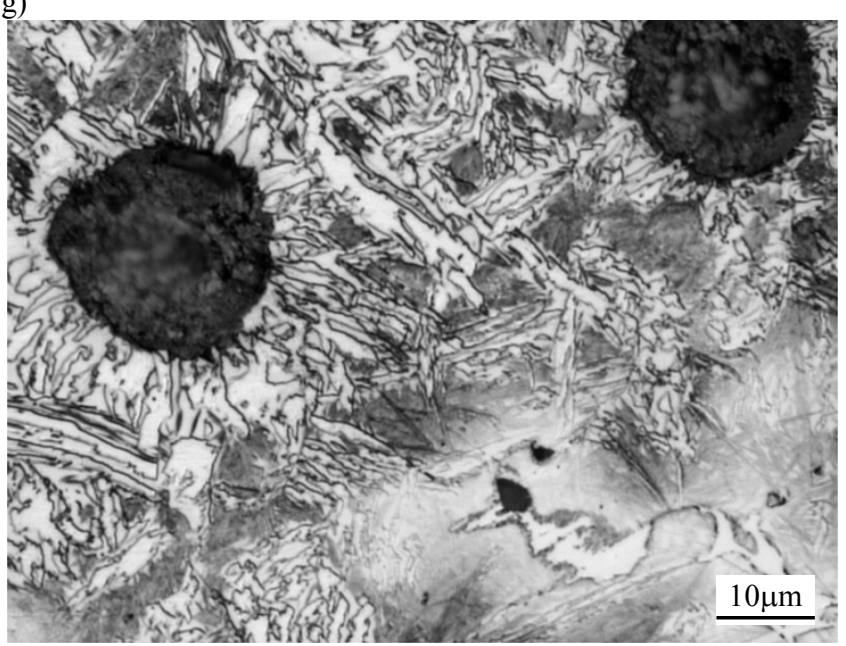

microstructure: nodular graphite, upper and lower bainite, carbides

Fig. $4(\mathrm{a} \div \mathrm{g})$. The microstructure of the investigated kinds of cast iron

From Fig. 4a indicates, that the microstructure of metal matrix ADI consists of ausferrite, which is a mixture of bainitic ferrite and austenite. The difference in the amount of carbides in cast iron metal matrix shown in Fig. 4b, $\mathrm{c}$ is caused by different concentrations of $\mathrm{Cr}$ at a similar concentrations of $\mathrm{Cu}$ and $\mathrm{Ni}$ ensuring obtaining pearlite during cooling in the mould. In the cast iron with upper bainite the different amounts of carbides were obtained using a higher concentration of Mo (Fig. 4e) and, additionally, Cr (Fig. 4f). A mixture of upper and lower bainite with carbides was obtained by increasing concentration of $\mathrm{Ni}$ in relation to the cast iron with upper bainite (Fig. $4 \mathrm{~g}$ ).

The hardness of examined kinds of cast iron are shown in Table 2 .

Figure 5 shows the results of abrasive wear cast iron works with 40 grit sandpaper. 
Table 2 .

The hardness of examined kinds of cast iron

\begin{tabular}{clc}
\hline No. & \multicolumn{1}{c}{$\begin{array}{c}\text { Type of cast iron metal matrix } \\
\text { and the proportion of the components }\end{array}$} & HB hardness \\
\hline 1. & ausferrite $100 \%$ & 255 \\
\hline 2. & pearlite $100 \%$ & 308 \\
\hline 3. & pearlite $90 \%$, carbides $10 \%$ & 360 \\
\hline 4. & upper bainite $100 \%$ & 272 \\
\hline 5. & upper bainite $95 \%$, carbides $5 \%$ & 293 \\
\hline 6. & upper bainite $88 \%$, carbides $12 \%$ & 411 \\
\hline 7. & upper bainite $67 \%$, lower bainite $30 \%$, carbides $3 \%$ & 477 \\
\hline
\end{tabular}

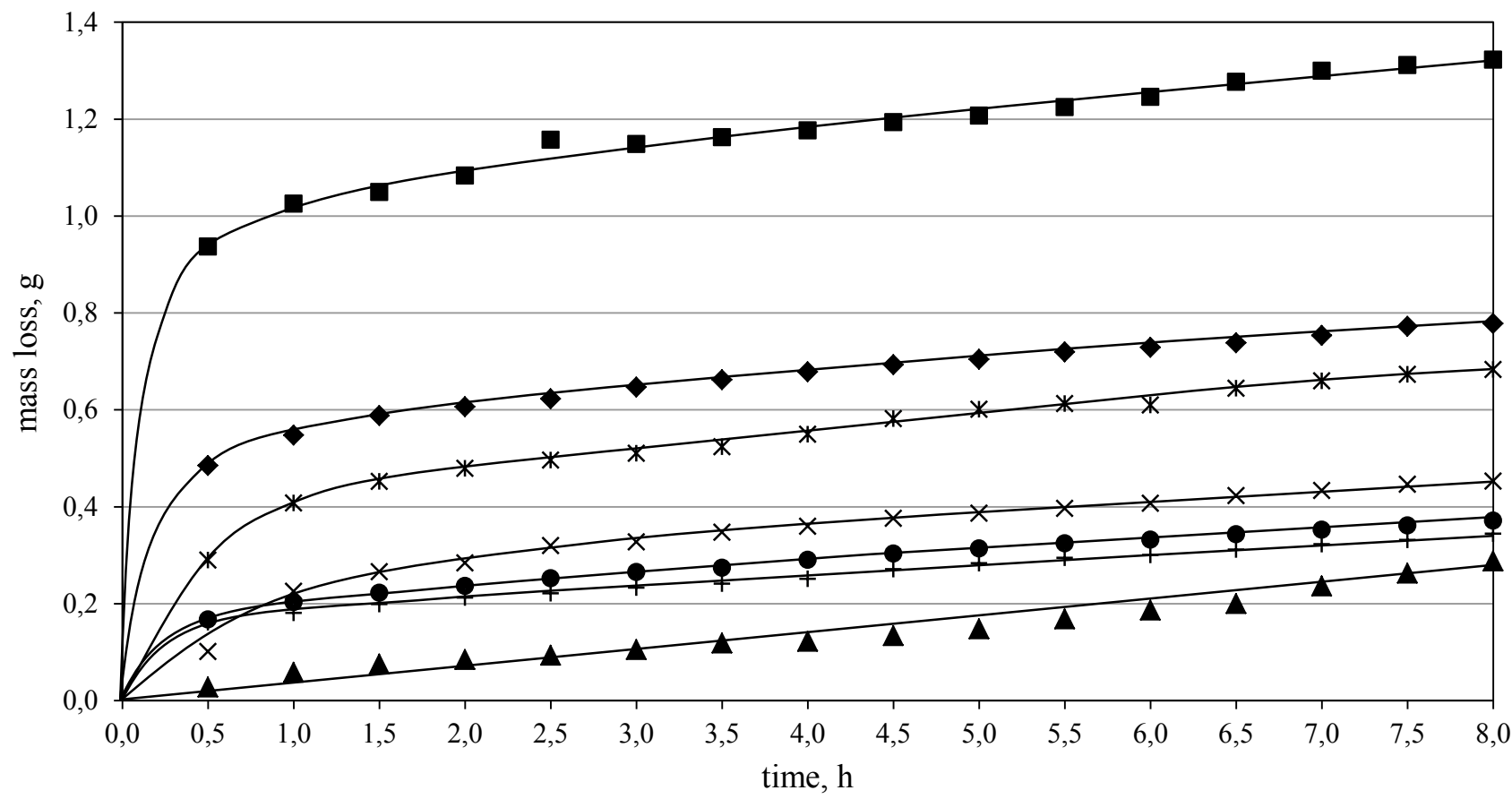

$\times$ ausferrite $100 \%$

- pearlite $90 \%$, carbides $10 \%$

- upper bainite $95 \%$, carbides $5 \%$ pearlite $100 \%$

* upper bainite $100 \%$

+ upper bainite $88 \%$, carbides $12 \%$

$\Delta$ upper bainite $67 \%$, lower bainite $30 \%$, carbides $3 \%$

Fig. 5. The effect of the type of nodular cast iron metal matrix on the abrasive wear resistance

From Table 2 shows that ADI is characterized by the lowest hardness among the studied kinds of cast iron. Cast iron with the upper bainite has a slightly higher hardness of at 272 HB. Carbides of about 5 and $12 \%$ cause an increase of that cast iron hardness respectively to 293 and $411 \mathrm{HB}$. Cast iron with upper and lower bainite and carbides had the highest hardness amounting $477 \mathrm{HB}$

In tested kinds of cast iron $(\mathrm{Fe}, \mathrm{Cr})_{3} \mathrm{C}, \quad(\mathrm{Fe}, \mathrm{Mo})_{3} \mathrm{C}$, $(\mathrm{Fe}, \mathrm{Cr}, \mathrm{Mo})_{3} \mathrm{C}$ ledeburitic carbides occurred and secondary $\mathrm{Mo}_{2} \mathrm{C}$ in cast iron containing molybdenum.

From Figure 5 indicates that character of wear the examined types of iron is similar. It is characterized by increased weight loss during early attempts. This is the running-in period. The exception is cast iron with carbides and upper and lower bainite, which did not show increased wear in the initial period of wear. It showed the smallest mass loss from all types of iron tested, amounting to $0.288 \mathrm{~g}$ after $8 \mathrm{~h}$ testing. It is almost twice lower compared to the ADI whose mass loss after $8 \mathrm{~h}$ test was $0.453 \mathrm{~g}$.

The lowest wear resistance showed a pearlitic nodular cast iron. Loss of weight in the first hour was over $1 \mathrm{~g}$ and after $8 \mathrm{~h}$ was $1.323 \mathrm{~g}$.

Cast iron with upper bainite matrix showed slightly smaller mass loss compared to pearlitic cast iron with carbides, but higher than ADI. A small (approximately 5\%) amount of carbides in the 
matrix metal has increased the wear resistance of cast iron with upper bainite. It showed a higher wear resistance compared to the ADI. The increase of carbides did not cause a significant increase in cast iron wear resistance. The difference in mass loss of both types of nodular cast iron with upper bainite were negligible throughout the period, and at the end was $0.027 \mathrm{~g}$, i.e. about $7 \%$.

Figure 6 shows the effect of the type nodular cast iron metal matrix on its adhesive wear resistance under conditions of Castrol oil lubrication.

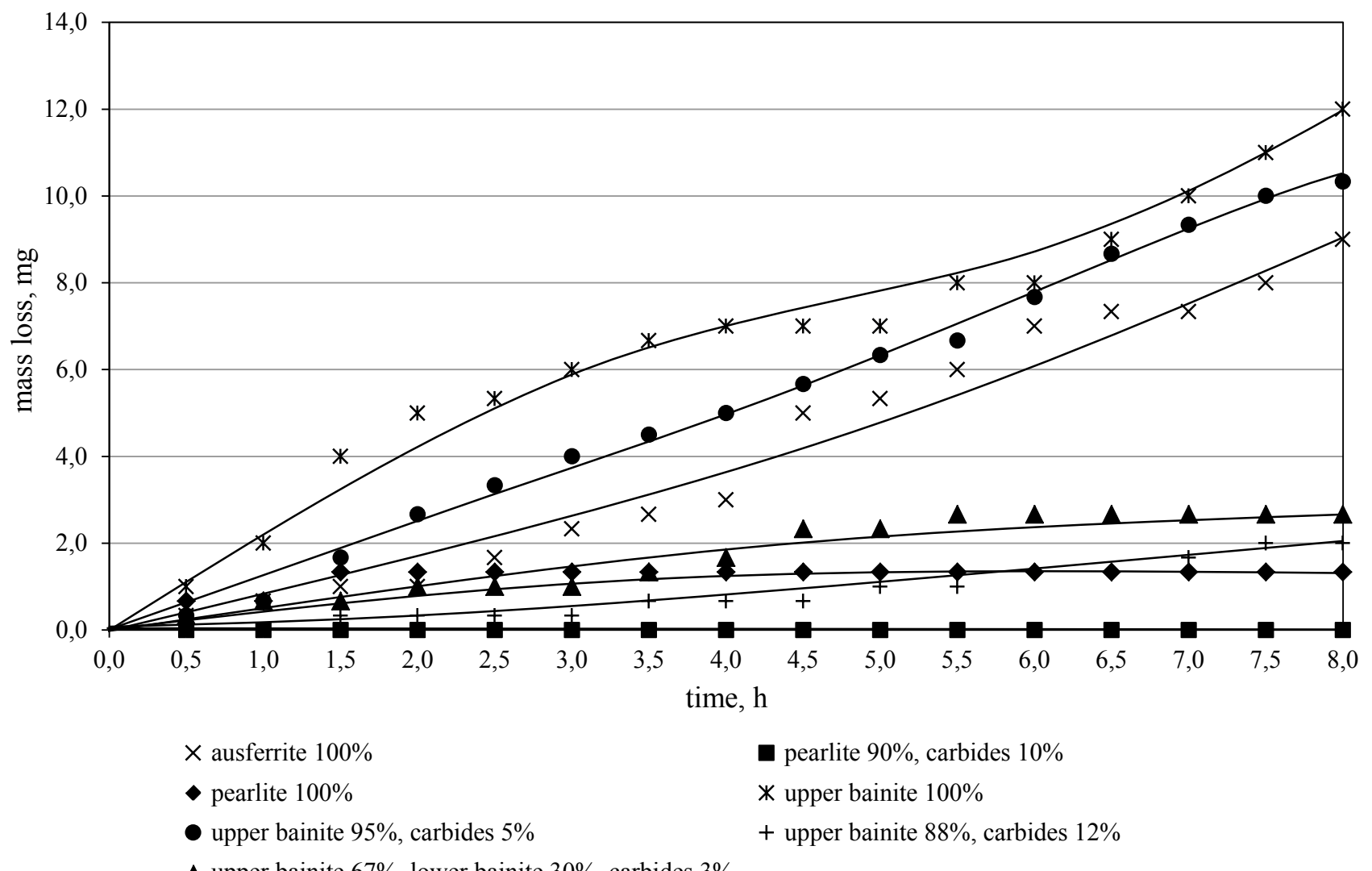

Fig. 6. The effect of the type of nodular cast iron metal matrix on its adhesive wear resistance under conditions of oil lubrication

From Figure 6 shows that the maximum mass loss of all tested types of cast iron does not exceed $12 \mathrm{mg}$. Cast iron with pearlitic matrix and carbides demonstrated the highest resistance to adhesive wear in oil lubrication conditions (no mass loss during the period). High wear resistance has shown also cast iron with pearlitic matrix. The loss in weight of the sample after eight hours of test was $1.3 \mathrm{mg}$. Nodular cast iron with carbides and upper and lower bainite showed loss equal to $2.6 \mathrm{mg}$, while with upper bainite and carbides in an amount of about $12 \%-2 \mathrm{mg}$. Other kinds of cast iron showed a greater loss. It ranged from $9 \mathrm{mg}$ for the ADI to $12 \mathrm{mg}$ for cast iron with the upper bainite and carbides of about $5 \%$.
The presented data show that the greatest resistance to adhesive wear of friction with oil shows a group of cast iron with a hardness in the range $308 \div 477$ HB (Table 2) and with microstructure of pearlitic with carbides, pearlitic, upper bainite with carbides in an amount of about $12 \%$ and upper, lower bainite and carbides. Cast iron with a hardness of about $255 \div 293 \mathrm{HB}$ showed significantly larger mass loss.

Influence of the type of nodular cast iron metal matrix to its resistance to adhesive wear in dry friction conditions are shown in Figure 7. 


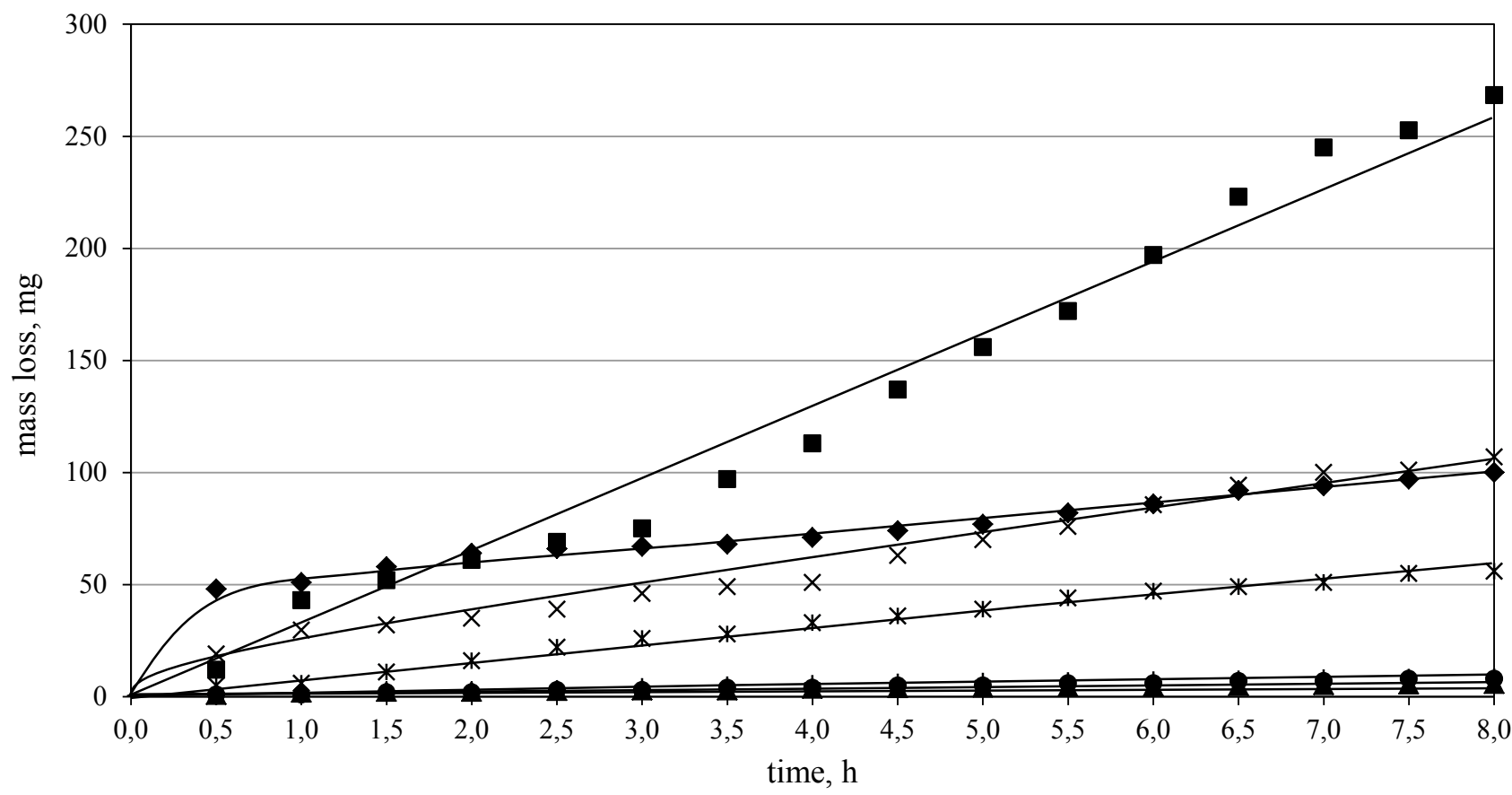

$\times$ ausferrite $100 \%$

- pearlite $90 \%$, carbides $10 \%$

- upper bainite $88 \%$, carbides $12 \%$

A upper bainite $67 \%$, lower bainite $30 \%$, carbides $3 \%$

pearlite $100 \%$

* upper bainite $100 \%$

+ upper bainite $95 \%$, carbides $5 \%$

Fig. 7. Influence of the type of nodular cast iron metal matrix on its adhesive wear resistance under conditions of dry friction

From Figure 7 indicates that the highest wear resistance in dry friction conditions shows a nodular cast iron metal matrix consisting of a mixture of upper and lower bainite and a small amount of carbides. Loss of weight after $8 \mathrm{~h}$ of friction was $5.8 \mathrm{mg}$ and was more than eighteen smaller in comparison with the ADI. A similar resistance to adhesive wear in dry friction conditions showed cast iron with upper bainite and carbides. Cast iron containing carbides in amounts 5\% showed mass loss equal to $9.2 \mathrm{mg}$, and with $10 \%$ $8 \mathrm{mg}$.

The lowest resistance to adhesive wear in the test conditions showed a pearlitic cast iron. Its weight loss was approximately uniform throughout the period, and after $8 \mathrm{~h}$ was $268.3 \mathrm{mg}$.

Another character of wear revealed pearlitic cast iron carbides. In the first 30 minutes its wear was highest and reached $48 \mathrm{mg}$, then weight loss was small and at the end of the test amounted to 100 mg. Slightly higher weight loss (about $7 \mathrm{mg}$ ) showed a ADI, but in its case the wear was uniform in the entire test period.

Nodular cast iron with the upper bainite showed approximately twice less wear compared to the ADI. The mass loss of the specimen was $56 \mathrm{mg}$ after the test.

\section{Conclusions}

Conducted research predispose to draw the following conclusions:

- nodular cast iron with carbides and upper and lower bainite is characterized by high wear resistance, far exceeding the ADI,

- the lowest abrasive wear resistance showed a cast iron with pearlitic matrix,

- $\quad$ cast iron group with the highest hardness and microstructure of pearlitic and bainitic shows the highest wear resistance at work with disc of tempered steel lubricated with oil,

- the most resistance to adhesive wear in dry friction conditions has nodular cast iron with carbides and bainite upper and lower,

- pearlitic cast iron shows the lowest resistance to adhesive wear in dry friction conditions,

- carbides in nodular cast iron increase the abrasive and adhesive wear resistance.

\section{Acknowledgments}

Scientific project financed from means of budget on science in years $2009 \div 2012$ as research project N508 411437 . 


\section{References}

[1] Pietrowski S. \& Gumienny G. (2006). Nodular cast iron with carbides. Archives of Foundry Engineering. 19, 233238 (in Polish).

[2] Pietrowski S. \& Gumienny G. (2006). Crystallization of nodular cast iron with additions of $\mathrm{Mo}, \mathrm{Cr}, \mathrm{Cu}$ and $\mathrm{Ni}, \mathrm{Ar}$ chives of Foundry Engineering. 22, 406-413 (in Polish).

[3] Pietrowski S. \& Gumienny G. (2008). Crystallization of nodular cast iron with carbides. Archives of Foundry Engineering. 8 (4), 236-240.

[4] Pietrowski S. \& Gumienny G. (2010). Bainite obtaining in cast iron with carbides castings. Archives of Foundry Engineering. 10 (1), 109-114.
[5] Gumienny G. (2010). Bainitic-martensitic nodular cast iron with carbides. Archives of Foundry Engineering. 10 (2), 6368.

[6] Gumienny G. (2010). Chromium and copper influence on the nodular cast iron with carbides microstructure. Archives of Foundry Engineering. 10 (4), 47-54.

[7] Gumienny G. (2008). Wear resistance of cast iron. Archives of Foundry Engineering. 8 (3), 173-180.

[8] Gumienny G. (2011). Wear resistance of nodular cast iron with carbides. Archives of Foundry Engineering. 11 (3), 8188. 